\title{
TARGETING POVERTY IN THE COURTS: IMPROVING THE MEASUREMENT OF ABILITY TO PAY
}

\author{
Meghan M. O’NeIL \& J.J. PRESCOTT*† \\ I \\ INTRODUCTION
}

Ten years ago, the police cited Alabama resident Harriet Cleveland multiple times for driving without car insurance. ${ }^{1}$ The state suspended Cleveland's license when she did not pay the fines she was assessed, notwithstanding her apparent inability to pay them. ${ }^{2}$ When Cleveland continued to drive so that she could get to work, she received additional tickets. ${ }^{3}$ By 2013 , although she had by then paid far more than the total face value of all of her tickets combined and thousands of additional dollars to a private probation company, her outstanding debt had grown to $\$ 2,714,{ }^{4}$ leading the court to issue a warrant for her arrest. The police arrested her in front of her grandson. ${ }^{5}$ The next day, the court required that she pay a total of $\$ 1,554$ immediately or serve a 31 -day jail sentence. ${ }^{6}$ Cleveland could not pay that amount on the spot, so she was taken straight to jail. ${ }^{7}$

Harriet Cleveland's story is not an outlier. In March 2015, the U.S. Justice Department issued a scathing report about police and court practices in the city of Ferguson, Missouri, that outlined the systematic criminalization of minor infractions, including illegal parking and lawn care violations. ${ }^{8}$ Fines were high

Copyright $@ 2019$ by Meghan M. O’Neil \& J.J. Prescott. Also available online at http://lcp.law.duke.edu/.

* Research Fellow and Professor of Law at the University of Michigan Law School, respectively. We are grateful to Poverty Solutions at University of Michigan's Ford School of Public Policy for research support and to Tomer Einat, Oren Gazal-Ayal, and an anonymous referee for useful comments on an earlier draft for a sentencing conference at the University of Haifa in May 2018.

+ Conflict disclosure: J.J. Prescott is a cofounder and equity holder of Court Innovations Inc. Court Innovations develops and implements online case resolution systems, including the Matterhorn ATP Assessment Tool, which is discussed and assessed at length in this article.

1. See Amended Complaint at 1, Cleveland v. City of Montgomery, 300 F.R.D. 578 (M.D. Ala. 2014) (No. 2:13-cv-00732-MEF-TFM) (outlining Cleveland's story through a complaint filed on her behalf by the Southern Poverty Law Center).

2. Id.

3. Id.

4. Id. at 4-5.

5. Id.

6. Id.

7. Id. at 2 .

8. U.S. DeP'T of Justice, InVestigation of the Ferguson Police DePartment 3, 7 (Mar. 4, 2015), https://www.justice.gov/sites/default/files/opa/press-releases/attachments/2015/03/04/ferguson _ 
and failure to pay produced cascading penalties: mounting fines and fees, license suspensions, and ultimately jail, ${ }^{9}$ sometimes even when ten times the initial fine amount had already been paid. Fines that require an in-person hearing to resolve may also disparately impact those who face greater barriers to physically going to court - such as lost wages from shift work, high childcare burdens, and hefty transportation costs. ${ }^{10}$ Unfortunately, Alabama and Missouri are not atypical jurisdictions in the United States; there are instances in all 50 states of impoverished people being jailed for supposed refusal to pay court debt in what the ACLU has coined modern-day debtor's prisons. ${ }^{11}$

In this article, we discuss the challenges of using fines as alternative sanctions, even for minor transgressions, when punishing the poor. While fines have considerable advantages in the abstract, setting and enforcing fines accurately is informationally demanding, particularly when offenders may lack the ability to pay them. Current court processes are poorly designed for imposing appropriate fines in these circumstances, producing the breakdowns on display in Alabama, Missouri, and across the United States. Fines too often counterproductively morph into back-breaking debts and even incarceration. Incorporating online two-way communication and resolution technology (which we refer to as "platform" technology) into the sanctioning process may improve matters: by increasing access, offenders may be better able to share critical information; by automatically collecting and organizing key data, judges may be better able to digest this information; and by standardizing the process and excluding legally irrelevant information, decisions may become less prone to implicit biases. After explaining how such technology works, we use interview, survey, and case-level court data to assess the experiences of the judges, administrators, and litigants of six courts that recently adopted an online ability-to-pay (ATP) assessment tool. We conclude that such technology has the potential to deliver better access to justice, accuracy in outcomes, and efficiency in how courts operate.

II

Fines AS ALternative SANCTIONS

Low-level violations of law are frequently penalized with fines. Although fines are often described as alternative sanctions, ${ }^{12}$ a sizeable majority of disputes between governments and citizens in the U.S. revolve around whether a court

police_department_report.pdf [https://perma.cc/M7R4-MG3B].

9. Id. at 3-4.

10. Id. at 48-49; see also SARAH MCLANAHAN \& GARY SANDEFUR, GROWING UP WITH A SINGLE PARENT: WHAT HURTS, WHAT HELPS 21, 85 (Harvard University Press 2009).

11. Joseph Shapiro, As Court Fees Rise, the Poor Are Paying the Price, NPR: ALL THINGS CONSIDERED (May 19, 2014), https://www.npr.org/2014/05/19/312158516/increasing-court-fees-punishthe-poor [https://perma.cc/QGK3-EFXF]; AM. CIV. LIBERTIES UNION, IN FOR A PENNY: THE RISE OF AMERICA'S NEW DEBTORS' PRISONS (2010), https://www.aclu.org/report/penny-rise-americas-newdebtors-prisons [https://perma.cc/B2UM-SH49].

12. Dan M. Kahan, What Do Alternative Sanctions Mean?, 63 U. CHI. L. REV. 591, 617 (1996). 
ought to impose a fine and, if so, what amount. ${ }^{13}$ The attractiveness of fines as a way to deter socially costly behavior is rooted in the efficiency of fines relative to incarceration and other forms of punishment. ${ }^{14} \mathrm{~A}$ fine is a transfer of wealth to the government, and therefore the government can use whatever it manages to collect to benefit the public-on top of deterring bad behavior, accomplishing retributive aims, and so on. By contrast, with the exception of community service, most categories of sanctions - for example, incarceration, corporal punishment, shaming, et cetera-operate by strategically destroying value, not transferring it elsewhere. ${ }^{15}$ Incarceration may improve welfare, but it is much less welfareimproving than using fines when both are able to achieve the equally valuable purposes of punishment. Using fines as sanctions thus allows us to have our cake and eat it too. We can appropriately punish antisocial behavior while covering our costs or even earning a profit. ${ }^{16}$

Fines do have their drawbacks, however. Society may be inclined to view the use of fines as announcing 'prices' for engaging in unlawful behavior, a statement that implicitly condones conduct that violates another's rights or harms the public so long as one can afford to pay the going rate. ${ }^{17}$ And, when someone seems likely to reoffend, fines may incapacitate poorly. Fines-especially flat fines - may also punish in a way that seems less fair than other kinds of sanctions. ${ }^{18}$ Two weeks in jail for a wealthy person and a poor person may appear more equitable than a fine that is small change for one person and a week's wages for another. Moreover, imposing fines can sometimes be a little too easy for governments, requiring checks on overcriminalization and overpunishment. ${ }^{19}$ Politicians increasingly realize that fine revenue need not be limited to paying for, say, law enforcement. ${ }^{20}$ Fines for trivial transgressions can fund all sorts of public projects, ${ }^{21}$ and those most injured by monetary sanctions (and accompanying add-

13. Minor disputes (e.g., traffic violations) account for significantly more than half of U.S. state court caseloads. J.J. Prescott, Improving Access to Justice in State Courts with Platform Technology, 70 VAND. L. REV. 1993, 2001 (2017).

14. Steven D. Levitt, Incentive Compatibility Constraints as an Explanation for the Use of Prison Sentences Instead of Fines, 17 INT'L REV. L. \& ECON. 179, 181 (1997); J.J. Prescott, Criminal Sanctions and Deterrence, ENCYClOPEDIA OF LAW AND ECONOMICS (2015) (Jürgen Backhaus, ed.).

15. See Levitt, supra note 14, at 179-80.

16. See R. Barry Ruback, The Benefits and Costs of Economic Sanctions: Considering the Victim, the Offender, and Society, 99 MINN. L. REV. 1779, 1781-84 (2015) (discussing the tradeoffs of using fines).

17. See Alexandra Natapoff, Misdemeanor Decriminalization, 68 VAND. L. REV. 1055, 1055 (2015).

18. Flat fines are regressive in the sense that the poor pay more than the wealthy per capita in relative terms. John Greenfield, Sliding-Scale Fines Could Make Chicago Traffic Enforcement More Equitable, CHI. READER (Sept. 28, 2016), https://www.chicagoreader.com/chicago/traffic-finesregressive-fees-solution/Content?oid=23730503 [https://perma.cc/542Y-49QH].

19. Natapoff, supra note 17, at 1059.

20. Id. at $1098-99$.

21. Peter Edelman identifies financial motivations and political imbalances as key sources of the current fines-and-fees crises. PETER EDELMAN, NOT A CRIME TO BE POOR: THE CRIMINALIZATION OF POVERTY IN AMERICA (2017). Reagan-era cuts created revenue gaps and so "the onus of paying for our justice system - from courts to law enforcement agencies and even other arms of government - began to shift to" litigants. $I d$. at xv. Today in the U.S., "ten million people ... owe a total of $\$ 50$ billion in accumulated fines, costs, fees, charges for room and board in jails and prisons, and other impositions." 
on fees) usually have little political clout to resist the creep of revenue-generating fines for regulatory violations or malum prohibitum offenses. ${ }^{22}$

One critical limitation of using fines as sanctions is that fines can only work when violators have sufficient resources to pay the amount they are deemed by the state to owe or, alternatively, the ability and opportunity to acquire those resources. ${ }^{23}$ Indeed, a general lack of financial liquidity is, at least for economists, the most straightforward reason why criminal justice cannot operate solely on the basis of fines. Even if it were politically and morally acceptable, imposing fines for serious crimes, such as rape or murder, would be ineffective because the appropriate penalty would be so large as to be impossible for many to pay. Although liquidity matters less often in the context of small fines for minor infractions - the average American can put together a few hundred dollars if necessary, even if doing so is difficult ${ }^{24}$ - even these small payments can be impossible for someone working paycheck to paycheck. By contrast, this abilityto-comply requirement is virtually never relevant in the incarceration setting: an offender may be ill or infirm, but incarceration of some sort is generally possible. $^{25}$

Thus, given the broad use of fines as sanctions by governments at all levels and the increasing inequality and stubborn poverty in the United States, ${ }^{26}$ it is important to understand how the justice system treats someone who claims to be unable to pay a court-ordered fine. An individual's ability to pay a fine is almost never substantively relevant under criminal statutes or ordinances. ${ }^{27}$ Accordingly, when offenders do not pay their fines, the default assumption is that they have

Id. at xiv. In Tulsa, Oklahoma, for example, "about 28 percent of the nearly 23,000 people booked into the Tulsa Jail in 2014 were arrested on court debt-related complaints." Id. at 8. Some criminal-justice systems use fines and fees in what some view as unseemly ways. Examples include: (1) Ferguson, Missouri, which used to impose a \$531 fine for high grass and weeds and (2) Allegan County, Michigan, which imposes a $\$ 500$ fee to help subsidize the costs of the courthouse gym. Id. at 7 .

22. As a result, the list of infractions producing fine revenue seems likely to grow over time, and policymakers may contribute to this growth by systematically overestimating the appropriate fine amounts. See Leah Plunkett, Captive Markets, 65 HASTINGS L.J. 57, 63 (2013)

23. Levitt, supra note 14 , at 180.

24. Derek Thompson, Very Sad Graph: How Much Americans Have Left to Spend After Essentials, Today, THE ATLANTIC (Aug. 1, 2012), https://www.theatlantic.com/business/archive/2012/08/very-sadgraph-how-much-americans-have-left-to-spend-after-essentials-today/260606/ [https://perma.cc/JN6ZGGYR]. Whether it is a good idea to force people to struggle to pay a fine is a hard question. The struggle may make the punishment more effective but may also destabilize lives in ways that counterproductively lead to more crime or other social costs.

25. Although the availability of accommodations for disabilities or physical ailments in jail or prison settings in some ways mirrors the divide in the fine context, physical health determinations are not left to judges to resolve but have instead been outsourced to professionals.

26. See generally Chetty et al., Is the United States Still a Land of Opportunity? Recent Trends in Intergenerational Mobility, 104 AM. ECON. REV. PAPERS \& PROC. 141 (2014); H. Luke Shaefer \& Kathryn Edin, Rising Extreme Poverty in the United States and the Response of Federal Means-Tested Transfer Programs, 87 SOC. SERV. REV. 250 (2013).

27. See Maura Ewing, Why Texas Courts Will Stop 'Nickel-and-Diming' the Poor, THE ATLANTIC (July 24, 2017), https:/www.theatlantic.com/politics/archive/2017/07/texas-court-fines/534363/ [https://perma.cc/ YZF7-UEAE] (discussing why the Texas legislature passed a law to curtail the practice of jailing those who are unable to pay court-imposed bills). 
effectively refused to comply with a court order and thus deserve contempt sanctions. ${ }^{28}$ However, the U.S. Constitution prohibits judges from incarcerating people who cannot pay fines and fees. ${ }^{29}$ Ability-to-pay determinations therefore primarily arise when a court finds itself in the position of resolving whether it may permissibly enforce a prior court order directing a litigant to pay a fine.

There are two critical inquiries when dealing with someone who does not comply with an order to pay a fine. The first is a threshold question: a court must determine whether the offender is refusing to pay the fine, but actually has the ability to and could voluntarily pay, or whether the offender is unable to pay.$^{30}$ If a court determines that someone is unable to pay a fine, the next question is whether there is some way to restructure the sanction-for instance, lowering the amount owed or spreading payments out over time-so as to render the offender 'able to pay' the new sanction. ${ }^{31}$ These inquiries seem simple enough, but grayarea cases abound. ${ }^{32}$ For example, consider someone with a $\$ 325$ fine and $\$ 400$ in the bank but with the $\$ 400$ budgeted for medicine and groceries. While employed, the individual is just getting by and cannot take on more hours at work because she is a full-time student and has a disability. ${ }^{33}$ In such cases, requiring full and immediate payment can produce real hardship, with the individual sacrificing housing, food, utilities, or other necessities (or the necessities of others, like children) to comply. ${ }^{34}$ The possibility of such hardship reveals not only the severity of even a modest fine for those not economically well off, ${ }^{35}$ but also that inaccurately assessed fines can harm third parties, such as family members, who are themselves innocent of any violation. ${ }^{36}$

Answering these two inquiries accurately for those who are economically disadvantaged is an informationally intensive exercise, and courts have not,

28. Katherine Beckett \& Alexes Harris, On Cash and Conviction, 10 CRIMINOLOGY \& PUB. POL'Y 509, 524 (2011); Ed Spillane, Why I Refuse to Send People to Jail for Failure to Pay Fines, WASH. PosT (Apr. 8, 2016), https://www.washingtonpost.com/posteverything/wp/2016/04/08/why-i-refuse-to-sendpeople-to-jail-for-failure-to-pay-fines/ [https://perma.cc/QUV3-RP4P].

29. Bearden v. Georgia, 461 U.S. 660, 672-73 (1983).

30. Id. at $667-68$.

31. Id. at 672-73. This analysis might also include a consideration of replacing the fine with another type of sanction, perhaps one easier to bear with fewer spillover effects: e.g., community service, so long as its scheduling does not interfere with the offender's livelihood. Kahan, supra note 12, at 625-30; Ken Pease, Community Service Orders, 6 CRIME \& JUST. 51, 51 (1985).

32. Beckett \& Harris, supra note 28, at 524-26.

33. In our research, we uncovered this specific scenario and similar ones in which judges needed to consider each factor individually - such as the type and extent of a disability-in determining a litigant's ability to pay and/or comply with an alternative sanction such as community service.

34. EDELMAN, supra note 21, at 10.

35. This is the traditional justification for using day fines, which are pegged to an individual's income or wealth to equalize the relative burden across people in different socioeconomic circumstances. See Beckett \& Harris, supra note 28, at 513-15.

36. We discovered what appear to be significant negative spillovers to children in the cases we study in this article. Several litigants expressed having to choose between shelter for their family during winter and complying with court-ordered fines. 
historically, performed the task well. ${ }^{37}$ The costs of inaccuracy in these evaluations can be very high for particular individuals, as evidenced by Harriet Cleveland's tribulations. Unfortunately, these challenging situations are not uncommon in the United States. And yet, despite their clear importance, abilityto-pay determinations as conducted by courts remain essentially unregulated and erratic. ${ }^{38}$ If an offender raises the issue of ability to pay, a court is theoretically obligated to make an inquiry, ${ }^{39}$ but when, how, and by whom is left to individual courts to decide. Before turning to platform technology's potential to improve the accuracy of these inquiries, we describe how many of today's courts conduct ability-to-pay determinations and share some evidence that the current approach is failing.

\section{III}

\section{THE CHALLENGE}

The words 'inefficient' and 'unnecessary' come to mind when reading stories about the enforcement of fines and fees in the United States, especially when they conclude with the jailing of someone who committed only a civil infraction. Fines are a common alternative to incarceration in the context of minor infractions, ${ }^{40}$ but local governments routinely spend large amounts of time, money, and effort to enforce fines for amounts that, even if received, in the end do not cover the enforcement costs themselves, much less bring in positive net revenue. ${ }^{41}$ Courts use various approaches to collect outstanding fines, ${ }^{42}$ but two of the most common strategies are driver's license suspensions - often regarded as acutely

37. Jessica M. Eaglin, Improving Economic Sanctions in the States, 99 MINN. L. REV. 1837, 1853-54 (2015) ("Moreover, states do not provide meaningful standards or methodologies for ability-to-pay determinations. For example, there is no consensus amongst courts as to when or how to determine ability to pay.").

38. See Beckett \& Harris, supra note 28, at 511-18.

39. Nicholas M. McLean, Livelihood, Ability to Pay, and the Original Meaning of the Excessive Fines Clause, 40 HASTINGS CONST. L.Q. 833, 833 (2013); see also ABA, STANDARDS FOR CRIMINAL JUSTICE, Standard 18-3.16, at 113 (3d ed. 1994), available at https://www.americanbar.org/content/dam/aba/ publications/criminal_justice_standards/sentencing.authcheckdam.pdf ("An offender's ability to pay should be a factor in determining the amount of the sanction. Sentencing courts ... should consider the offender's obligations, particularly family obligations.") (on file with Law \& Contemporary Problems).

40. See Karin D. Martin et al., Monetary Sanctions: Legal Financial Obligations in U.S. Systems of Justice, 1 ANN. REV. CRIMINOLOGY 471, 471-95 (2018) (discussing why legal financial obligations are routinely imposed for minor offenses); ALEXES HARRIS ET AL., MONETARY SANCTIONS IN THE CRIMINAL JUSTICE SYSTEM (2017), http://www.monetarysanctions.org/wp-content/uploads/ 2017/04/Monetary-Sanctions-Legal-Review-Final.pdf [https://perma.cc/H7NC-HH83].

41. Matthew Menendez, Fees and Fines Threaten Judicial Independence, ABA J. (Apr. 19, 2018), http://www.abajournal.com/news/article/fees_and_fines_threaten_judicial_independence [https://perma.cc/22NH-FTXR]; see also Daniel S. Nagin, Thoughts on the Broader Implications of the “Miracle of the Cells," 7 CRIMINOLOGY \& PUB. POL'Y 37, 37-42 (2008) (observing that enforcing fines is resource intensive).

42. Alexes Harris et al., Drawing Blood from Stones: Legal Debt and Social Inequality in the Contemporary United States, 115 AM. J. SoC. 1753, 1759 (2010); Douglas EvANS, THE DEBT PENALTY: EXPOSING THE FINANCIAL BARRIERS TO OFFENDER REINTEGRATION 7-8 (Aug. 2014), https://jjrec.files.wordpress.com/2014/08/debtpenalty.pdf [https://perma.cc/B2Z2-4V88]. 
counterproductive because complying with the suspension order interferes with one's ability to earn money to pay the fine and ignoring the order often leads to more fines ${ }^{43}$ - and bench warrants, which seek to force compliance with the threat of incarceration. When courts use these strategies, even those who begin owing small amounts of money can end up in jail. And when the threat of jail results in actual jail because the offender does not pay, the efficiency benefits of using fines as sanctions evaporate since the costs of jailing someone will often if not virtually always exceed the value of any fines the court might eventually recover.

Although the U.S. Constitution mandates that the imposition of jail time-or any additional fine or fee-for noncompliance must be premised on an individual's ability to pay the initial fine, ${ }^{44}$ the Supreme Court has said little about how this assessment must or even should be made by courts. ${ }^{45}$ Ability-to-pay determinations thus operate in an openly ad hoc way (if they operate at all), ${ }^{46}$ and procedures vary dramatically from court to court and from judge to judge. ${ }^{47}$ An example of how this situation translates to practice can be found in a recent Michigan State Court Administrative Office report on how to carry out abilityto-pay determinations:

The "ability to pay" must be determined and applied on an individual basis. Each judge, for each obligor brought before the court for failure to pay a court-ordered financial obligation, must review the required facts and circumstances and make an individual determination of the obligor's ability and resources to pay the ordered monetary assessments and whether the obligor has made a good-faith effort to pay. Judges may have differing philosophies regarding ability to pay and may weigh facts in a given case differently. A judge's discretion is tempered by the confines of the law and should be exercised with fairness and restraint. Ultimately, each decision is up to the individual judge. $^{48}$

For better or worse, judges are not trained in how to assess personal finances, identify the indicators of poverty, or evaluate the destabilizing effects of even

43. Alicia Bannon et al., Criminal Justice Debt: A Barrier to Reentry, BRENNAN CTR. FOR JUST. (2010), http://www.brennancenter.org/sites/default/files/legacy/Fees \%20and\%20Fines \%20FINAL.pdf [https://perma.cc/KU8T-2EAD].

44. Bearden v. Georgia, 461 U.S. 660, 668 (1983) ("If the probationer has willfully refused to pay the fine or restitution when he has the means to pay, the State is perfectly justified in using imprisonment as a sanction to enforce collection.").

45. Eaglin, supra note 37, at 1849 ("Judges enjoy a great deal of discretion when imposing economic sanctions. Very little guidance exists on how or when to use this sanction.").

46. In some courts, consideration of a litigant's ability to pay is an afterthought, at best. EDELMAN, supra note 21, at 8 ("In practice 'the judges don't make an inquiry before finding that the defendants are able to pay. The only thing the judges know about our defendants' ability to pay is that they are so poor they can't bond out.' The Tulsa World reported that 'one woman explained [to the presiding judge] that she had to choose between having her electricity cut off and paying her court cost.' The judge explained that the court's remedies are the same as those of the electric company, only the court's version is sending people to jail."); see also id. at 11, 29-30, 40.

47. See Eaglin, supra note 37, at 1839-40 (detailing how courts differ in evaluating an individual's ability to pay); Shapiro, supra note 11.

48. See Mich. Supreme Court State Court Admin. OfFice: Ability to PAy Workgroup, TOOLS AND GuIDANCE FOR DETERMINING AND AdDRESSING AN OBLIGOR's ABILITY TO PAY 6 (Apr. 20, 2015) http://courts.mi.gov/Administration/SCAO/Resources/Documents/Publications/ Reports/AbilityToPay.pdf [https://perma.cc/HB9Y-9FFG] [hereinafter MICHIGAN REPORT]. 
small fines on struggling families. ${ }^{49}$ Instead, judges are simply directed to do the best they can, taking into account their own philosophies of punishment, to determine whether an offender is making good-faith efforts to satisfy their fines. Judicial discretion need only be tempered by the confines of the law.

Because there is little consistency with respect to how judges usually make ability-to-pay determinations, it is impossible to quantify whether judges as a class or as individuals are generally accurate in their assessments - other than by looking to the large numbers of people jailed for outstanding fines and to other aggregate statistics indicating system failure. ${ }^{50}$ Many thousands of Americans each year face serious sanctions for refusing to pay fines, apparently "choosing" to ignore outstanding warrants for their arrest-and therefore denying themselves social services and the protection of law enforcement as well as regularly going to jail for days, weeks, or even months - rather than pay a few hundred dollars that they are assumed to have. ${ }^{51}$ In some jurisdictions, as many as one in five jail inmates are incarcerated for failure to pay court debt. ${ }^{52}$ These outcomes alone belie the idea that all or even most of these people are able, but simply refusing, to pay. ${ }^{53}$ Even if some judges are generally accurate in their assessments of a debtor's ability to pay, we cannot know how much variance there is in their accuracy across types of cases and classes of litigants. ${ }^{54}$ Just as important, some judges are likely to be systematically inaccurate, and some classes of litigants are likely to be systematically misappraised, perhaps because they lack social or cultural common ground with their judge. In this context, anecdotes or small sample studies can be informative. ${ }^{55}$

49. See Ruback, supra note 16, at 1806 ("Most courts do not have a written plan for how such a determination should be made.").

50. See, e.g., Eaglin, supra note 37, at 1864 n.176 (discussing how one organization measured Rhode Island's system failure and found that " $18 \%$ of all jailings were on account of failure to pay court debts," and that each offender owed, on average, \$826).

51. Furthermore, if an individual on probation or parole fails to pay a fine in full, judges can - and often do-return them to jail. See, e.g., Ebony Ruhland, The Impact of Fees and Fines for Individuals on Probation and Parole, ROBINA INST. CRIM. L. \& CRIM. JUST., https://robinainstitute.umn.edu/newsviews/impact-fees-and-fines-individuals-probation-and-parole [https://perma.cc/C3ME-5KB5].

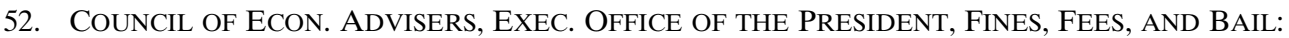
PAYMENTS IN THE CRIMINAL JUSTICE SySTEM THAT DisPROPORTIONATELY IMPACT THE POOR 1 (Dec. 2015), https://obamawhitehouse.archives.gov/sites/default/files/page/files/1215_cea_fine_fee_bail_ issue_brief.pdf [https://perma.cc/LPY8-B2ZR].

53. See Spillane, supra note 28; Shapiro, supra note 11.

54. See, e.g., LAwYERS' COMM. FOR Civil Rights OF THE S. F. BAy AREA, PAYING MORE FOR BEING POOR 19 (2017), https://www.lccr.com/wp-content/uploads/LCCR-Report-Paying-More-forBeing-Poor-May-2017.pdf [https://perma.cc/R23G-XREJ] ("[N]o county was able to provide information on the criteria used to make ability to pay determinations.").

55. See, e.g., BANNON ET AL., supra note 43, at 21 (discussing how one judge in Illinois determines that any defendant who smokes cigarettes is able to pay); AM. CIVIL LIBERTIES UNION OF NEB., Unequal Justice: Bail and Modern Day Debtors' Prisons in Nebraska, at 29-30 (2016), https://www.aclunebraska.org/sites/default/files/field_documents/unequal_justice_2016_12_13.pdf [https://perma.cc/9S65-E32H] (describing how judges in three Nebraskan counties never inquire into ability to pay); Molly Jackson, Michigan Supreme Court Cracks Down on Pay or Stay Imprisonment, CHRISTIAN SCI. MONITOR (Jan. 4, 2016), https://www.csmonitor.com/USA/Justice/2016/0104/MichiganSupreme-Court-cracks-down-on-pay-or-stay-imprisonment [https://perma.cc/6E9U-MG3V] ("One 
One potential source of inaccuracy in current ability-to-pay determinations is the role expected of litigants in the process. Our adversarial system relies on the active, full-throated participation of all parties to ensure accurate and fair outcomes. ${ }^{56}$ Yet fear and confusion keep many people out of court altogether, as do the financial, physical, and psychological barriers to going to a courthouse in person. ${ }^{57}$ Of course those actually unable to pay fines also cannot afford lawyers, and because of the nature of their cases (e.g., fines and civil incarceration), they have no right to publicly provided counsel and very little access to legal aid. ${ }^{58}$ Pro se litigants fare notoriously poorly relative to represented litigants. ${ }^{59}$

Limited understanding of the justice system and fear of courts and judges may also limit a litigant's willingness to engage fully in any hearing ${ }^{60}$ and may inhibit a litigant from asserting inability to pay as a defense in the first instance; judges will not raise the issue sua sponte. ${ }^{61}$ Many poor litigants have no idea that they cannot lawfully be incarcerated by a court when they are unable to pay. ${ }^{6}$ More knowledgeable litigants, who wish to claim indigency, know they stand before the court as defendants, violators, and offenders. In such a posture, these litigants may be especially intimidated by judges, bailiffs, and other court officials or perhaps unable to communicate effectively because they fear public speaking. ${ }^{63}$ As a consequence, they may prefer instead to default in the overly optimistic hope that they can successfully avoid courts and the police in the future. ${ }^{64}$

judge told NPR that he guesses whether a person can pay based on their clothing and appearance.").

56. Ellen E. Sward, Values, Ideology, and the Evolution of the Adversary System, 64 IND. L.J. 301, 302 (1989).

57. Maximilian A. Bulinski \& J.J. Prescott, Online Case Resolution Systems: Enhancing Access, Fairness, Accuracy, and Efficiency, 21 MICH. J. RACE \& L. 205, 222-24 (2016).

58. See Natapoff, supra note 17, at 1084 ("Many courts routinely incarcerate civil contemnors for failing to pay fines without giving them a lawyer."); Louis S. Rulli, On the Road to Civil Gideon: Five Lessons from the Enactment of a Right to Counsel for Indigent Homeowners in Federal Civil Forfeiture Proceedings, 19 J.L. \& POL'Y 683, 697 (2011).

59. Richard W. Painter, Pro Se Litigation in Times of Financial Hardship-A Legal Crisis and Its Solutions, 45 FAM. L.Q. 45, 46 (2011); Jona Goldschmidt, The Pro Se Litigant's Struggle for Access to Justice, 40 FAM. CT. REV. 36, 37 (2002) (explaining how represented parties usually prevail in litigation against pro se litigants).

60. Bulinski \& Prescott, supra note 57, at 218-19; Prescott, supra note 13, at 2007-08.

61. States vary in terms of whose burden it is to raise an ability-to-pay issue and the timing of any inquiry. HARRIS ET AL., supra note 40, at 16. In Michigan, for example, a litigant is only entitled to an ability-to-pay assessment when the imposition of the fine is enforced, not when the judge initially imposes the fine, thus leaving the burden on the litigant of both raising the ability to pay issue and proving indigence. AM. CIV. LIBERTIES UNION, supra note 11, at 31.

62. See Joseph Shapiro, Supreme Court Ruling Not Enough to Prevent Debtors Prisons, NPR: MORNING EDITION (May 21, 2014), https://www.npr.org/2014/05/21/313118629/supreme-court-rulingnot-enough-to-prevent-debtors-prisons [https://perma.cc/K4B5-6Q7Z] (explaining how debtor prisons were outlawed in the United States over 200 years ago); AM. CIV. LIBERTIES UNION, supra note 11, at 48.

63. See Bulinski \& Prescott, supra note 57, at 229.

64. J.J. Prescott, Assessing Access-to-Justice Outreach Strategies, 174 J. InST. \& THEORETICAL ECON. 34, 38-39 (2018). 
Even when litigants are assertive and aware of their rights, those who are poor and low-income are more likely to be financially illiterate and inexperienced ${ }^{65}$ making it difficult for them to convince a judge that they are unable to pay a particular fine. Indigent individuals often do not have the necessary means-on many levels - to present a complete and representative picture of their financial situation to a court. Many litigants arrive unprepared and without proper supporting documentation, ${ }^{66}$ leaving judges to make decisions on the basis of limited and potentially distorted evidence. ${ }^{67}$ Moreover, because litigants rarely understand the law and substance of the ability-to-pay inquiry, they may fail to mention financial factors outside the judge's specific line of questioning (for instance, their partial support of an aging parent or the income fluctuations common to gig-based jobs).

Meanwhile, examples abound of judges using systematically unreliable rules of thumb in making their ability-to-pay determinations. For instance, "a judge in Illinois asked all defendants if they smoked, and when any said yes, the judge said they have the means to pay." ${ }^{68} \mathrm{~A}$ judge in another jurisdiction concluded that a "defendant had expensive-looking shoes or the like and therefore must be able to pay," and a "judge in Michigan found that because the defendant had cable television he was capable of paying." ${ }^{69}$ Judges have been known to consider litigants' sneakers, manicured nails, or even tattoos in their ability-to-pay determinations ${ }^{70}$ assuming a strong correspondence between litigants' access to resources (including gifts) in the past and their present financial condition. Although clothing and appearance can sometimes be relevant to understanding a litigant's financial wherewithal, ${ }^{71}$ it is not difficult to imagine that cultural assumptions about appropriate spending and lifestyle priorities could predispose a judge to a particular conclusion and that any such predisposition could vary with a litigant's age, class, race, gender, or national origin. ${ }^{72}$

It is also possible that inaccuracy in ability-to-pay determinations stems from pervasive judicial confusion about what ability to pay means or that judges simply

65. See Annamaria Lusardi \& Peter Tufano, Debt Literacy, Financial Experiences, and Overindebtedness, 14 J. PENSION ECON. \& FIN. ECON. 332, 340 (2015).

66. Stephan Landsman, The Growing Challenge of Pro Se Litigation, 13 LEWIS \& CLARK L. REV. 439, 449 (2009).

67. See Painter, supra note 59, at 47 (explaining why judges find it more difficult to make accurate determinations in pro se litigation).

68. EDELMAN, supra note 21, at 5.

69. Id.

70. MichigAN REPORT, supra note 48; EDELMAN, supra note 21.

71. See, e.g., John M. Conley \& William M. O'Barr, Crime and Custom in Corporate Society: A Cultural Perspective on Corporate Misconduct, 60 LAW \& CONTEMP. ProbS., Summer 1997, 5, 9 (discussing how people draw inferences from an individual's appearance or clothing).

72. See Olivia C. Jerjian, The Debtors' Prison Scheme: Yet Another Bar in the Birdcage of Mass Incarceration of Communities of Color, 41 N.Y.U. REV. L. \& SOC. CHANGE 235, 250 (2017) ("This lack of definition has opened up the meaning of 'ability to pay' to judges' subjective interpretations and explicit or implicit bias on what that term concretely means, with results that can vary even within the same state."). 
too often draw knee-jerk inferences that are poorly supported by the facts or are just internally inconsistent. ${ }^{73}$ In Pittsburgh, an analysis of 4,500 failure-to-pay cases indicated that in more than 4 out of 5 cases judges failed to meet a basic requirement of explaining their conclusion that the defendant had refused to pay. ${ }^{74}$ Furthermore, in $10 \%$ of the cases (involving more than 200 defendants), judges explicitly noted uncontroverted facts that actually supported a defendant's inability to pay - such as "defendant is homeless[,] unable to pay;" "defendant has been evicted;" and "defendant has no income"-in the record documenting their decision to incarcerate the defendant for refusal to pay. ${ }^{75}$ Thus, even if courts - in good faith-actively endeavor to assess the ability of litigants to comply with their financial penalties in a consistent way, the necessarily ad hoc and inaccessible in-person process makes it very difficult for judges to reliably divine litigants' socioeconomic status. ${ }^{76}$

All of this inaccuracy in determining ability to pay in our courts generates serious social costs. Jailing or fining those who are unable to pay inflates the collective price tag of the justice system and creates unnecessary, concentrated harm for particular individuals with no compensating social benefits. ${ }^{77}$ And if those who are improperly jailed also lose their jobs or public benefits the social cost of inaccuracy is even greater. Additionally and importantly, these errors can foster distrust and even hatred toward the justice system as a whole. ${ }^{78}$ A litigant inaccurately found (or assumed) to be able to pay a fine may emerge from the experience viewing courts as illegitimate, concluding that courts generally make decisions on the basis of mistaken cultural beliefs or aesthetic preferences rather than on genuine financial considerations.

\section{IV}

\section{POTENTIAL SOLUTIONS}

Thanks to the recent focus on the fines-and-fees crisis by the U.S. Justice Department and other organizations,${ }^{79}$ policymakers in many states are re-

73. See AM. CiV. Liberties UNION, supra note 11, at 37 ("Courts across the state are just as arbitrary in their handling of probation revocations based on a defendant's ability to pay fees.").

74. Kate Giammarise \& Christopher Huffaker, Jailed Over Unpaid Fines, Court Costs: Debtors' Prisons?, U.S. NEWS \& WORLD REP. (Feb. 24, 2018, 3:01 AM), https://www.usnews.com/news/beststates/pennsylvania/articles/2018-02-24/jailed-over-unpaid-fines-court-costs-debtors-prisons (on file with Law \& Contemporary Problems).

75. Id.

76. See Bulinski \& Prescott, supra note 57.

77. See, e.g., Eaglin, supra note 37, at 1853 ("[T]he additional cost municipalities pay to punish debtors may outweigh the amount recovered through collection.").

78. EDELMAN, supra note 21, at xi.

79. The ACLU has recommended that "consistent guidelines regarding determination of indigence and policies for assessing and collecting [legal financial obligations] should be implemented in every jurisdiction to guard against arbitrary or racially skewed discrepancies in punishment." The ACLU report further recommends that judges receive (unspecified) training in making ability-to-pay determinations. AM. CiV. LiBERTIES UNION, supra note 11, at 11. 
examining how courts ought to handle ability-to-pay determinations. ${ }^{80}$ A number of recent reforms at the state level aim to reduce arbitrariness and improve accuracy by mandating hearings, imposing more robust standards, and providing guidance on pertinent ability-to-pay considerations. This Part details a few of these reforms, briefly critiques them, and outlines a proposed alternative solution based not on legal reform but on online platform technology.

In May 2016, the Michigan Supreme Court handed down rules that explicitly targeted existing weaknesses in state court ability-to-pay hearings. ${ }^{81}$ The rules reiterate that judges must determine ability to pay and may not jail offenders unless they find "the defendant is able to comply ... without manifest hardship and ... has not made a good-faith effort to comply." 82 Courts must evaluate a litigant's ability to pay and must make findings of fact on the record before incarceration becomes an option. ${ }^{83}$ The rules also expound on the relevant financial considerations, imbuing them with somewhat more substance. For instance, courts are directed to evaluate: "basic living expenses including but not limited to food, shelter, clothing, necessary medical expenses, or child support." 84 In other words, courts must consider the listed categories and yet must also explicitly ask whether there are any other types of expenses that ought to be counted as "basic living expenses" as part of the ability-to-pay assessment.

Other states have likewise taken action to provide more structure and clarity to the relationship between monetary sanctions and an individual's ability to pay. ${ }^{85}$ For example, Ohio recently mandated that judges use ability-to-pay bench cards, guides that set forth restrictions on the use of incarceration for criminal justice debt. ${ }^{86}$ Confinement is now only available after a determination, following a hearing, that the litigant is willfully refusing to pay, and such a determination must be accompanied by findings of fact regarding the litigant's income, assets, and debts. ${ }^{87}$ Colorado now prohibits incarceration "when a defendant is unable to pay... without undue hardship to himself or herself or his or her dependents." 88 Ohio's requirements may operate to limit judicial discretion, but the potential for "racially skewed discrepancies in punishment" remains. ${ }^{89}$

80. See, e.g., Ewing, supra note 27; Joe Duggan \& Martha Stoddard, Nebraska Lawmakers Pass Bills Dealing with 'Debtor Prisons,' Budget and More, OMAHA WORLD-HERALD (May 9, 2017), https://www.omaha.com/news/legislature/nebraska-lawmakers-pass-bills-dealing-with-debtor-prisonsbudget-and/article_efe56e87-9704-5afa-992e-c3f0ddbe8235.html [https://perma.cc/YKY9-YUQM].

81. Mich. Supreme Court, ABILITy to PAy COURT Rule AMENDMENTS MEMORANDUM (Aug. 16, 2016), http://courts.mi.gov/Administration/SCAO/OfficesPrograms/TCS/Documents/TCS\% 20Memoranda/ TCS-2016-25.pdf [https://perma.cc/VB5F-7EGW].

82. Id.

83. Id. at 2 .

84. Id.

85. Neil L. Sobol, Charging the Poor: Criminal Justice Debt \& Modern-Day Debtors' Prisons, 75 MD. L. REV. 486, 527-28 (2016).

86. Id. at 529 .

87. Id.

88. Id. at 531.

89. AM. CIVIL LIBERTIES UNION, supra note 11, at 11. 
Colorado's reforms seem to improve the prospects of someone being found unable to pay when appropriate by explicitly including the negative effects of payment on dependents as considerations in judicial determinations ${ }^{90}$ However, the statute does not define undue hardship, which ensures ongoing ambiguity in any hearing. ${ }^{91}$

In the end, these reforms are relatively minor. They operate by fine-tuning existing law (e.g., adjusting a legal standard), providing behavioral nudges in the right direction (e.g., checklists and list-based definitions), and mandating that findings of fact be made on the record. Judges retain considerable discretionnot only in making their final ruling, but in how they structure the process. In Michigan, for instance, significant heterogeneity remains in the questions judges ask, the evidence judges demand from litigants, and the time judges take to collect information and rule on a litigant's ability to pay. ${ }^{92}$ This wide variation in process likely occurs not only across judges, but even from litigant to litigant appearing before the same judge. ${ }^{93}$ Nor do these reforms address the central role that litigants must play in setting the trajectory and shaping the contours of their ability-to-pay determination. ${ }^{94}$ Even when courts are legally obliged to make ability-to-pay rulings in every case, litigants must actively participate in their hearings to have any chance of succeeding. ${ }^{95}$

An alternative approach to improving ability-to-pay determinations is technological. Some courts have recently begun to experiment with online platform technology, which is designed to improve litigant engagement, process consistency, information availability, hearing efficiency, and ultimately decisionmaking accuracy. The technology operates by connecting litigants directly to law enforcement or court officials, including judges, over the internet using computers or mobile devices. ${ }^{96}$ Thus, it offers an alternative to in-person hearings when appearing in court would be burdensome. Platform technology can also guide communication, allowing the sharing of information in a structured and transparent way. ${ }^{97}$ For this reason, it has the potential to improve congruence across courtrooms and to reduce costly error, even the imposition of undeserved

90. $C f$. Am. Civil Liberties Union of Colo., Justice Derailed: A Case Study of Abusive AND UnCONSTITUTIONAL PRACTICES IN COLORADO CiTy COURTS 21 n.16 (2017), https://acluco.org/wp-content/uploads/2017/10/JUSTICE-DERAILED-web.pdf [https://perma.cc/ZA7U-P8FB].

91. Cf. Saul Levmore, Ambiguous Statutes, 77 U. CHI. L. REV. 1073, 1077-78 (2010) (discussing how ambiguities in statutes permits judicial gap-filling).

92. See AM. Civ. LiBerties Union, supra note 11, at 37.

93. See id.; see also Chris Guthrie et al., Blinking on the Bench: How Judges Decide Cases, 93 CORNELL L. REV. 1, 31 (2007).

94. See Sward, supra note 56, at 312; Marvin E. Frankel, The Search for Truth: An Umpireal View, 123 U. PA. L. REV. 1031, 1038 (1975) ("Our courts wait passively for what the parties will present, almost never knowing - often not suspecting - what the parties have chosen not to present.").

95. See AM. Civ. LiBERTIES UNION, supra note 11, at 17 (discussing how judges only make abilityto-pay determinations "if the defendant appears in court to assert his inability to pay").

96. Bulinski \& Prescott, supra note 57, at 241.

97. See id. at 242-44 (outlining how an online platform system can standardize and enhance court processes and judicial decision making). 
and ineffective jail time ${ }^{98}$ and the effects of systemic bias, such as the unfair practices documented in Ferguson, Missouri. ${ }^{99}$ While not yet common, online court platform technology is no longer rare and its footprint is growing. ${ }^{100}$

In 2017, six courthouses in Michigan-most serving populations with aboveaverage rates of poverty -implemented platform-based online ability-to-pay assessment software: the Matterhorn ATP Assessment Tool. ${ }^{101}$ Before reporting on the measurable experiences these courts have had with the tool, we briefly summarize how it operates. Matterhorn is available online at any time of day to anyone who has outstanding eligible fines or fees with an adopting court. ${ }^{102}$ About $40 \%$ of Matterhorn users access the system during nights, weekends, and early mornings. ${ }^{103}$ Litigants begin the online process by entering identifying information - their name, date of birth, and driver's license number - into the web-based interface to review their outstanding fines, fees, or warrants. The tool then presents users with a series of carefully worded questions to collect critical information, using skip patterns and simple algorithms to help litigants provide a complete picture of their financial stability to the court. ${ }^{104}$

Matterhorn begins by simply asking litigants whether they can pay what they owe. ${ }^{105}$ If a litigant claims to be unable to pay, additional questions explore why the litigant reports being unable to pay. ${ }^{106}$ If the litigant has employment income,

98. See AM. Civ. LiBERTIES UniOn, supra note 11, at 28 (arguing that New Orleans wastes money every day to incarcerate people who will never be able to pay their debts).

99. See Stephen Deere, Chuck Raasch \& Jeremy Kohler, DOJ Finds Ferguson Targeted AfricanAmericans, Used Courts Mainly to Increase Revenue, ST. LOUIS POST-DisPATCH (Mar. 5, 2015), https:/www.stltoday.com/news/local/crime-and-courts/doj-finds-ferguson-targeted-african-americansused-courts-mainly-to/article_d561d303-1fe5-56b7-b4ca-3a5cc9a75c82.html [https://perma.cc/7VEULUVM].

100. Joint TeCh. COMM., Online Dispute Resolution FOR COURTS 1 (Nov. 29, 2017), https:/www.ncsc.org/ /media/Files/PDF/About\%20Us/Committees/JTC/JTC\%20Resource\%20Bulleti ns/2017-12-18\%20ODR\%20for\%20courts\%20v2\%20final.ashx [https://perma.cc/BJ2ETJNE]. Matterhorn, one of the earliest court-based platform communications systems, has contracts as of this writing with approximately forty courts in eight states and has supported the resolution of tens of thousands of cases. MATTERHORN, https://getmatterhorn.com/ [https://perma.cc/24BY-7TPH] (last visited July 5, 2018). Matterhorn is now used in both district and circuit courts to resolve many types of disputes by facilitating communication and reducing the burden of litigation.

101. Please note again that Prescott has a proprietary interest in the Matterhorn ATP Assessment Tool and its owner, Court Innovations Inc.

102. Some eligible litigants - especially indigent ones - may be unable to access the tool because they lack access to the internet. Bulinski \& Prescott, supra note 57, at 236. Importantly, all litigants remain eligible for a traditional in-person assessment if they do not have internet access.

103. We calculated these operations statistics using user data from courts adopting the ATP assessment tool as a separate platform through April 3, 2018. All calculations are available from the authors upon request.

104. The system populates the tool with information available from other sources, including court records, and in the long run, the tool is likely to be linked to other government agency databases, making data collection even more straightforward.

105. This question takes different forms, including, "Can you pay X within X timeframe?"; "What is your plan of payment?"; and "How much can you afford and how often?"

106. These questions include: "Are you in bankruptcy?"; "Do you have income from a source that is not government assistance?," in which government assistance is specifically defined; and "Do you have assets such as savings/investment accounts or property?" 
the tool asks the litigant to categorize their status (for example, full-time, parttime), and then to provide a total income estimate. If the litigant reports no income, the system asks the litigant to account for that fact. ${ }^{107}$ Depending on these answers, the assessment tool may follow with questions about the litigant's current sources of cash or any other periodic support-whether from family, friends, loans, or odd jobs-for acquiring necessities. The tool also collects detailed information about the litigant's assets, if any: real-estate equity, vehicles, savings, and investments. It then turns to expenses: first, personal expenses in the last month, including clothing, personal care, dining out, and entertainment; second, general expenses, including dependent children, any mortgage or rent amounts, utilities, insurance, healthcare costs, loan payments, child support, and alimony. ${ }^{108}$ Finally, the assessment tool asks the litigant to list any special circumstances about which the court should be aware, giving the litigant an opportunity to supply - at length, in their own words, on their own time, and while in a setting of their own choosing - any reasons why their answers to the previous questions regarding income, assets, and expenses might paint an inaccurate financial picture.

The assessment tool automatically distills all of these data into key summary indicators that are made available online to the judge examining the case. ${ }^{109}$ This summary information includes what aims to be an objective assessment of how the litigant's financial circumstances compare to various definitions of poverty, and also presents aggregated information on income, assets, and expenses, along with basic details about the litigant's employment status and extenuating circumstances. The litigant's written communications with the court are cleanly organized for judicial review, and the judge is free to explore all of the original answers to any question, along with any supporting documents, which litigants can easily upload directly to the court using their mobile device or computer. ${ }^{110}$

Ultimately, there is nothing revolutionary about the idea that using technology in this way can facilitate ability-to-pay determinations. Yet there are several reasons to believe that implementing such technology, like Matterhorn, may improve outcome accuracy relative to other proposed reforms. First, it makes the ability-to-pay determination less burdensome, scary, and confusing for

107. The tool asks: "Are you able to work?"; "Have you ever been employed?"; "Are you currently unemployed?"; "What kind of work have you done in the past?"; and "Do you need help finding work?"

108. The system also allows courts to explicitly direct litigants to submit necessary documentation for these entries online, which litigants can do using a mobile phone camera.

109. See Guthrie et al., supra note 93, at 35-36 (arguing that "judges facing cognitive overload due to heavy dockets or other on-the-job constraints are more likely to make intuitive rather than deliberative decisions" and that courts therefore need to reform and simplify procedures in order to make more considered decisions).

110. By design, a platform-based ability-to-pay determination does not involve the judge orally asking the litigant questions in a face-to-face setting (maybe the same questions the judge has asked a thousand times - or worse, maybe different questions, in light of the litigant's appearance or the judge's mood). Nor does it involve the judge recording any of the litigant's answers, collecting copies of litigant documents, or other time-consuming but administrative tasks that distract from the key decisions to be made. These are all accomplished by the tool directly. 
litigants; and by doing so, it encourages them to participate more often and allows them to do so more effectively. ${ }^{111}$ Second, it offers a consistent, standardized approach to gathering data, one that seeks to balance building a comprehensive picture against overwhelming litigants with a never-ending series of inquiries. ${ }^{112}$ Consequently, litigants are more likely to supply judges with what they need to make an accurate decision. ${ }^{113}$ Third, the online process saves judges time by collecting and assembling the most relevant data in advance, mitigating any urge judges might have to skip steps or to choose speed over accuracy. ${ }^{114}$ This technology-based approach, which can be incrementally improved over time, will almost always produce a more comprehensive record than the ordinary barebones in-person hearings that characterizes typical ability-to-pay processes today, and it gives judges the room they need to bring their expertise to bear when it is most helpful. Fourth, the process is fixed in advance and therefore applied equally to everyone, regardless of race, gender, or class, ${ }^{115}$ and the entire exchange between the litigant and the court can be recorded for later audit. ${ }^{116}$

\section{$\mathrm{V}$ \\ EMPIRICAL EVIDENCE}

In this part, we summarize the early experiences of six Michigan courts that adopted the Matterhorn online platform for ability-to-pay determinations. Our goal is very modest. We are interested in whether platform technology has the potential to improve accuracy through better litigant access, enhanced data collection and aggregation, greater consistency, and less susceptibility to implicit bias. Our work has significant limitations. We explore a single ability-to-pay assessment platform as implemented in six courts in a single state. We examine the experiences of early-adopter courts, which are unlikely to be representative or helmed by typical judges. All opinions and outcomes are preliminary ones, based on short experiences and often very little data. Unlike other court platform technology studies, ${ }^{117}$ we are unable to use system implementation timing to study differences in outcomes post-adoption.

Studying the accuracy of ability-to-pay determinations in this setting is a particular challenge because we have no objective measure of outcome accuracy in our data (i.e., we cannot tell whether a judge "got it right"). Consequently,

111. See Bulinski \& Prescott, supra note 57, at 219 (noting that cognitive hurdles in the legal process "may ultimately culminate in [litigants] choosing (perhaps subconsciously) to ignore their legal issues").

112. Id. at 229 (explaining how online platform technology helps overcome some of the challenges of collecting information from litigants in a courtroom).

113. Id. at 230 .

114. Id. at 244 .

115. Id. at 248 (finding that the online platform technology "may be able to provide a judge with all the information that he needs to resolve the case accurately, while obscuring information that is useless or that might introduce impermissible bias into the decision-making process.").

116. Id. at 213-14.

117. See, e.g., Prescott, supra note 13; Prescott, supra note 64. 
many traditional evaluation methods are infeasible. ${ }^{118}$ To assess the potential of platform tools to improve outcome accuracy, we instead rely on various proxies and employ a mixed methods analysis, compiling evidence from semi-structured qualitative interviews of key court personnel, participant observation, surveys, and case-level court information. This multi-faceted strategy has advantages when evaluating small intensive pilot projects and offers flexibility when analyzing a dynamic relationship between a private actor (Matterhorn's developer), state actors (the six courts and their administrators and judges), and the public. ${ }^{119}$ However, in this preliminary work, we must lean heavily on judgeand litigant-reported satisfaction and related reactions to the platform-based approach as rough proxies for accuracy in ability-to-pay determinations. Not surprisingly, there are many good reasons to question the strength of any assumed correlation between participant satisfaction and outcome accuracy. ${ }^{120}$ Consequently, our empirical contribution is limited. We recommend drawing, at most, tentative lessons from this exercise and instead encourage readers to formulate testable hypotheses on the basis of our data to lay the groundwork for future research.

The study begins with the launching of the Matterhorn ATP Assessment Tool in six pilot state district courts. ${ }^{121}$ Five of the six courts had prior experience using technology of this sort to resolve cases. All platform launches occurred within the last two years; our data collection took about three months and began before any court had been using the platform for more than a year. ${ }^{122}$ Our sample courts serve mostly diverse urban areas, ${ }^{123}$ which have average poverty rates ranging from $16-50 \% .{ }^{124}$ Common disadvantages facing these litigant populations include difficulty speaking English and physical disability-concrete barriers to

118. An alternative approach would be to look at long-run outcomes that would allow us to infer earlier accuracy, such as reduced jail time imposed for outstanding fines and fees, but we were unable to collect these data, and our sample period was also relatively short.

119. William G. Axinn \& Lisa D. Pearce, MiXed Method Data Collection Strategies (2006).

120. For example, judges may report satisfaction with online platforms because they reduce timeconsuming, in-person hearings, while litigants may report satisfaction because they believe they are able to obtain more favorable (but not necessarily more accurate) outcomes.

121. Court 1 launched on March 15, 2017. Court 2 launched on April 15, 2017. The four remaining courts, separate courthouses that are part of a single district court, launched on August 1, 2017. All courts were district courts dedicated to traffic and lower-penalty infractions. The ATP assessment tool in Courts $3,4,5$, and 6 was integrated directly into a warrant resolution solution, meaning that only individuals with outstanding warrants had access to the online tool.

122. Specifically, in January, February, and March of 2018, at which point each court had used the online court software regularly for at least five months. One implication of the short post-period is that the patterns we detect may only represent short-term effects.

123. The exceptions are two smaller courts-one in a rural and one in a suburban region - that use the ATP assessment tool as part of a larger district court adoption. These courts represent a small fraction of our sample in terms of litigant population (approximately $5 \%$ ), but their use of the tool at all hints that even affluent jurisdictions serve litigants who can benefit from remote ATP determinations.

124. We calculated the demographics of our sample jurisdictions using American Community Survey data. See U.S. Census Bureau Factfinder, accessed Apr. 10, 2018. All calculations are available from the authors upon request. 
navigating the judicial system - as well as poverty, as indicated by the common receipt of government benefits.

We interviewed all seven key court personnel (judges, magistrates, and court administrators $)^{125}$ that used the Matterhorn assessment tool at the time of this evaluation. ${ }^{126}$ Five interviews were conducted in person and two were conducted over the phone. ${ }^{127}$ We audio recorded and took notes intermittently throughout every interview. Interviews averaged seventy minutes in length. All participants walked us through the online process in their court, with one judge inviting us to observe her as she deliberated over and resolved actual cases in real time using the platform assessment tool. ${ }^{128}$ During this 75 -minute participant observation we were able to monitor how the judge handled ability-to-pay determinations at every step-as well as the ultimate decisions and forms of relief offered. All statements we report below are verbatim, with the exception of statements collected during the participant observation, which are as close to exact as possible given the judge's request that we not record any identifying information or other highly specific data regarding individual cases.

The interviews and our observations indicate that judges are generally quite enthusiastic about using online technology to assess ability to pay. Decisionmaker enthusiasm is of course not tantamount to improved accuracy. However, this judicial satisfaction appears to derive from features of the assessment tool that make judges more confident in the accuracy of their decisions. Judges emphasize the tool's ease of use and the fact that comprehensive, relevant data are conveniently delivered all to one place. Judges also maintain that the tool promotes the development of a standard process for resolving ability-to-pay determinations, enhancing consistency across cases. Finally, judges report less unproductive back-and-forth with litigants relative to open court, fewer searches for paper documents, and greater litigant understanding of the process. These effects all translate to requests being handled sooner, mitigating the costs that deter litigants from invoking their rights. All of these themes, which we discuss in more depth below, can be seen in one judge's account:

125. Subjects averaged 50 to 59 years old. Most were female. All judges and magistrates who adopted the assessment tool were female. Two court administrators were male. All were American-born, nonHispanic white, and highly educated. Two identified as Independents, one as a Democrat, and the others declined to identify with any particular political party.

126. For examples of purposive sampling in studying courts, see Rhys Hester, Judicial Rotation as Centripetal Force: Sentencing in the Court Communities of South Carolina, 55 CRIMINOLOGY 203, 20335 (2017); Matthew Clair \& Alix S. Winter, How Judges Think About Racial Disparities: Situational Decision-Making in the Criminal Justice System, 54 CRIMINOLOGY 332, 337-40 (2016).

127. O'Neil conducted all interviews, surveys, and data compilation. As a founder, equity holder, and board member of Court Innovations, Prescott had and continues to have a conflict of interest in any evaluation of Matterhorn online platform tools (including the ATP assessment tool), and so in addition to disclosing this conflict, we limited Prescott's exposure to participants and his involvement in data collection and analysis whenever possible.

128. For a well-regarded application of this same approach, albeit with a larger sample, see Issa Kohler-Hausmann, Misdemeanor Justice: Control Without Conviction, 119 AM. J. SoC. 351, 359 (2013). Although identifying information was revealed during the ethnographic portion of the evaluation, we only recorded pseudonyms. 
We have these baskets with tickets. Well, first I receive a request on my system, at which point my clerk pulls the ticket and places it in this basket [points to basket, picks up the phone and calls the clerk] "Jaime, please get me the Smith ticket for my inbox, ok, thanks?" [Clerk comes in momentarily with printed ticket stamped with a note on the bottom directing people to access ATP on the court's website if they are unable to pay the fine in full]. I don't keep it in the "in basket" for long. The system reminds me how long it's been since the case opened and I like to wrap it up within a day or so, providing the defendant my response right away so we can proceed. It's definitely faster than what we do in-house. See here [judge holds up the ticket] this driver is driving a new car, so she has some money, but here in the system she tells me about being in school full-time, her disability, her overhead, and how little she makes, etc. Oh, and look at her age, she's just a kid, lives with her parents. [Judge begins adding figures out loud $-\$ 120$ insurance, $\$ 65$ groceries, $\$ 289$ tuition ... . I I'm going to offer her a six-month payment plan, at $\$ 50$ a month. As soon as she makes the first payment, we drop her warrant. Just like that! In the "out basket" for the clerk to file. ${ }^{129}$

Despite the variation in the populations served by these courts and the fact that different courts have different needs, judges offered similar positive opinions regarding the Matterhorn assessment tool during the interviews. In essence, judges claimed that the assessment tool made their decisions better and improved the process for both court personnel and litigants. ${ }^{130}$

Importantly, the judges we interviewed report feeling better informed when they use the online assessment tool to appraise ability to pay. Our subjects explicitly remark that the tool delivered more and better information relative to an in-person hearing, giving judges more to consider in most situations. Admittedly, people can be very poor judges of whether their performance has improved in response to a change in their information environment. ${ }^{131}$ Judges who perceive that the assessment tool provides more comprehensive information in a distilled and easier-to-digest format may be lulled into false optimism about their decision-making accuracy. ${ }^{132}$ Nevertheless, we believe these reactions are at least somewhat informative, given the objective reasons to believe that the tool presents better information to judges and that judges are able to spend less time and effort collecting, organizing, and reviewing information and more time deliberating.

Relatedly, judges report that the platform-based assessment tool makes the ability-to-pay determination and sanction resolution process both easier and more efficient. Despite providing judges with more - and more comprehensiveinformation, the tool also streamlines information acquisition, organization, and

129. Qualitative sociological interview-based studies rely on sometimes lengthy quotations as evidence of interviewer's experience in lieu of quantitative metrics, which are less practical in smallsample studies. See, e.g., Pete Simi et al., Addicted to Hate: Identity Residual Among Former White Supremacists, 82 AM. SOC. REV. 1167, 1173 (2017).

130. This positive impression may have spawned interest in using platform technology to handle other court matters and spontaneous suggestions of other ways such technology might improve court operations. The six sample courts have also adopted several other online tools, including software that assists litigants in regaining their driver's license after a suspension.

131. Raymond S. Nickerson, Confirmation Bias: A Ubiquitous Phenomenon in Many Guises, 2 ReV. GEN. PSYCHOL. 175, 188-89 (1998).

132. See Donald C. Nugent, Judicial Bias, 42 Clev. ST. L. REV. 1, 5-6 (1994) (describing how judges can have a "false sense of confidence in their decisions"). 
processing, producing generally faster determinations relative to in-person hearings. One judge commented:

\begin{abstract}
Some ATP cases take me two-to-three minutes to make my determination, some take more, depends on the circumstances. I get more info, better info from [the assessment tool]. Like, I don't want to embarrass people in a public hearing. When a defendant is standing before me in open court and begging for a payment plan because they are disabled and been out of work for long period of time ... with the ATP system they can share with me-and they do-and I can respond accordingly. Like if they provide me with an indication of having [Social Security Income] and tell me they struggle with transportation to the court because of their heart condition, I now have more facts with which I can make a determination what type of community service the court may want to offer, if any, and understand the need for a payment plan. $\left.{ }^{133}\right]$ When I have a full house, there is no way I have time to assess people's needs in the way I can using the ATP program. Two-to-three minutes, the system streamlines it, giving me exactly the info I ask for and the defendant also has the option to write me a note and they do, many of them anyhow.
\end{abstract}

Our interview data also reveal a number of unanticipated benefits from courts using platform technology to conduct their ability-to-pay determinations. For example, many judges were pleased that the tool's technology allows for easy adjustments to the online procedure, both large and small, even after the launch of the platform. This attribute delivers the potential to encourage, reward, and institutionalize incremental accuracy-enhancing improvements in the ability-topay assessment process as well as in how the software operates.

Developer responsiveness, of course, is not intrinsic to an online platform approach, but flexibility and adaptability is an innate aspect of using software to carry out court tasks. ${ }^{134}$ In contrast to in-person hearings, where judicial flexibility raises concerns about the inconsistent treatment of litigants, the fact that judges can lock in improvements to their own processes, which would then apply consistently to all litigants before that judge, encourages refinements and attention to potential enhancements that, if successful, can become standard practice. ${ }^{135}$ Such improvements can be shared with other judges, too, boosting the diffusion of beneficial ideas. Likewise, subtle process problems need only be identified once by a single decision-maker to be remedied system-wide. ${ }^{136}$

Our interview data indicate that judges, magistrates, and court administrators would generally welcome a responsive, evolving solution to case processing and resolution, especially in the particular context of high-volume, low-stakes cases. ${ }^{137}$ Collectively, our subjects report that they too often face bureaucratic barriers to change, dampening their interest in developing better approaches to their tasks,

133. One judge stated that offering community service as an alternative sanction was challenging without knowing the litigant's limitations, if any: for example, she did not want to offer street clean-up to someone physically disabled as it may not be respectful of their needs and/or limitations.

134. See Bulinski \& Prescott, supra note 57, at 243 (describing how the envisioned online platform is adaptable to the users' needs); Prescott, supra note 13, at 2022 n.157.

135. See Bulinski \& Prescott, supra note 57, at 226-27 n.114 (explaining how online platform systems allow for frequent updates and modifications).

136. See id. at 244 (arguing that platform technology will facilitate transparency across courts, given the data-sharing components of these systems).

137. See Prescott, supra note 13, at 2031 n.187. 
which may in turn have long-term consequences for outcome accuracy. They view platform technology as at least a partial solution to this problem. Importantly, however, our interview population is unrepresentative; it comes only from earlyadopter courts and is almost certainly biased in favor of technology adoption and innovation. Even so, the ability of software generally to guide, refine, and animate legal procedures suggests that platform technology affords us an opportunity to transform how courts operate on the ground by encouraging regular experimentation and incremental improvement. ${ }^{138}$

Finally, the interview data also reveal that there are spillover benefits to using platform technology that are not directly related to the accuracy of online determinations or to the benefits enjoyed by other litigants. For instance, online platform technology has the propensity to reduce crowding and delay in courthouses. Judges view this as an unanticipated, but critically important, positive outcome. ${ }^{139}$ As one judge elaborated: "ATP reduces the number of people in the building, which increases safety. It definitely shortens the dockets...." Fewer people waiting in and around courtrooms makes for a more comfortable, less hurried environment, ${ }^{140}$ which may promote more accurate decision making. Judges also have more time to conduct in-person hearings, and litigants are less rushed to make their arguments and present their evidence, presumably increasing a court's capacity for accurate outcomes. ${ }^{141}$

To complement our interview data, we also surveyed our subjects. ${ }^{142}$ Surveys have demonstrated value in criminal justice research as a cost-effective and rapid mechanism for gaining insight into judicial beliefs, decision making, and behavior. ${ }^{143}$ We readily admit that interviewing and surveying the same subjects

138. To be clear, such a transformation is by no means certain, at least in the short run. Some of the same barriers to change that make platform software like the assessment tool so potentially valuable are also sure to hinder the adoption of the technology itself. For instance, one magistrate asserted that many judges are allergic to change and have a particular aversion to technology. So, while it is clear that the traditional in-person approach to measuring ability-to-pay is failing, it is far less clear how willing judges will be to reform the measurement process if doing so means transforming their jobs in ways that are unfamiliar or even scary. Charles W. Nihan \& Russell R. Wheeler, Using Technology to Improve the Administration of Justice in the Federal Courts, 1981 BYU L. REV. 659, 663-64; Fred Galves, Where the Not-So-Wild Things Are: Computers in the Courtroom, the Federal Rules of Evidence, and the Need for Institutional Reform and More Judicial Acceptance, 13 HARV. J.L. \& TECH. 161, 169-70 (2000).

139. Each interviewee commented on the benefits of having fewer litigants in the courthouse at any time and on how this improved public safety and reduced costs for security personnel. Presumably, a lesscrowded courthouse also improves litigant comfort levels, as well.

140. See Prescott, supra note 13, at 2031 n.187 (suggesting that the implementation of platform technology could reduce delays for all litigants - including those that do not use the technology).

141. See id. at 2020 (explaining how online platform technology allows parties to communicate and resolve cases in a virtual space).

142. We acknowledge that we were only able to survey seven individuals from what are likely to be unrepresentative, early-adopter courts. Although we take some comfort in the facts that we surveyed the full universe of court personnel who were heavily involved in the Matterhorn pilot and that the evidence we discuss are the unanimous or near-unanimous views of the subjects, the potential for sampling bias is high and readers should view all results with a decent measure of caution.

143. See, e.g., Shawn Bushway et al., An Explicit Test of Plea Bargaining in the "Shadow of the Trial," 52 CRIminology 723, 723-54 (2014); Theodore Eisenberg \& Valerie P. Hans, Taking a Stand on Taking 
necessarily double counts evidence to some extent by relying repeatedly on the same source. Still, there are good methodological reasons for surveying and interviewing subjects in this context. First, we were able to ask a number of questions more carefully and easily using the survey format-and ask the same questions of each respondent with the same wording and in the same order. ${ }^{144}$ Second, we distributed the survey to our respondents before we conducted the interviews, and the answers we received to our questions allowed us to more effectively develop a strategy for our open-ended, one-on-one meetings. We therefore believe the survey evidence we present ought to be accorded some weight, despite the double counting implicit in doing so.

Consistent with our interview data, survey takers unanimously report that the ability-to-pay assessment tool saved time for judges and courts and provided better, faster access to justice for litigants relative to the traditional in-court process. All but one respondent found the online assessment tool to be a comparable or more comprehensive way to evaluate litigants' ability to pay. Our judge and magistrate respondents agreed with the statement that the tool "can help keep people out of jail," suggesting an awareness that some people sent to jail for failure to pay a court debt are presently misclassified, either because those people never sought or received an ability-to-pay determination or because their in-person hearings somehow came to the wrong conclusion. Judges also believe that compliance rates with the online tool are the same or higher relative to standard practices, and that "some to half" of litigants would not be able to successfully resolve their ability-to-pay dispute without access to the tool.

Most respondents contend that the tool is easier to use and less biased than in-person ability-to-pay determinations. Specifically, judges feel that minorities, the elderly, the disabled, and non-English speakers obtain better access to justice using the assessment tool. As part of the survey, our respondents completed a photo-matching vignette exercise, ${ }^{145}$ a set of tasks known for its ability to identify bias and obtain potentially more honest answers on controversial topics. ${ }^{146}$ Respondents examined photographs that depicted people of varying ages and skin tones in situations illustrating various themes including substance abuse, military service, physical disability, homelessness, domestic violence, and obesity. We asked respondents to indicate, upon first instinct, whether the subjects could benefit from the assessment tool. ${ }^{147}$ There was broad consensus that the tool

the Stand: The Effect of a Prior Criminal Record on the Decision to Testify and on Trial Outcomes, 94 CORNELL L. REV. 1353, 1366-69 (2009).

144. The survey also involved an exercise that would not have translated well to an interview setting.

145. For examples of how this methodology can be used, see Jeffrey J. Rachlinski et al., Does Unconscious Racial Bias Affect Trial Judges?, 84 Notre DAME L. ReV. 1195, 1217-18 (2009); Taylor Jillian Altman, A Crime at Any Age: Intimate Partner Abuse in Later Life, 105 CAL. L. REV. 1543, 1552 (2017).

146. Rhidian Hughes \& Meg Huby, The Construction and Interpretation of Vignettes in Social Research, 11 SOC. WORK \& SOC. SCI. REV. 36, 45-46 (2004); Guillermina Jasso, Safeguarding Justice Research, 41 SOC. METHODS \& RES. 217, 217-39 (2012).

147. Gillian Bendelow, Pain Perceptions, Emotions and Gender, 15 Soc. HeAlTH \& IlLNESS 273, 278-79 (1993); Pranee Liamputtong, Researching the Vulnerable: A Guide to SENSitive 
could mitigate hidden biases, at least with regard to age, appearance, gender, minority status, and physical disability. ${ }^{148}$

The survey data also show that our judge respondents believe they can communicate more directly and candidly with litigants when using the tool. Judges confess feeling more comfortable raising sensitive topics with litigants like disability, addiction, and mental health - that could be embarrassing to discuss in open court. Judges also indicate using the tool to make referrals to Alcoholics Anonymous, legal aid, social services, and mental health centers. All but one judge expressed interest in making such referrals a built-in option to consider during the online ability-to-pay determination process to further improve their communication with litigants. Judges report significant concern that litigants often have untreated mental health and substance use disorders that interfere with their compliance, employment, and ability to pay.

While the experiences that judges, magistrates, and court administrators describe having had with the Matterhorn assessment tool are useful in understanding platform technology's potential to improve the accuracy of abilityto-pay determinations, the views and experiences of litigants are equally if not more important. Accuracy relies critically on litigant participation and engagement in the ability-to-pay determination process. To better understand litigants' experiences, we examined responses to a survey sent electronically to all litigants who used the ability-to-pay assessment tool three days after a judge decided their case. The nine-question survey investigates the value of remote court access and the fairness of the online process, and asks whether the litigant would have been able to appear in court in the absence of the online tool.

As we previously stated, our litigant user survey sample size is very small, and so the evidence we present is merely suggestive. ${ }^{149}$ Nevertheless, the data support a first-blush positive appraisal of the online assessment tool. Over $75 \%$ of all respondents indicate that they would not have been able to appear in court had the court not made the tool available. As a proxy for compliance, this figure suggests that just $25 \%$ of respondents would have been able to satisfy their initial alleged legal obligation. ${ }^{150}$ One litigant described feeling helpless as he set off to deal with his outstanding warrant: "I was desperate to handle the situation and began using google." After obtaining a payment plan using the Matterhorn tool,

RESEARCH METHODS 141-47 (2007).

148. One judge reported that she did not want addicts using the software, preferring to see them in person to ensure they were "serious about treatment" before considering relief.

149. At the time of our analysis, the developer had electronically sent surveys to 238 individuals. Twenty-nine people had returned the survey as of April 13, 2018, a response rate of over $12 \%$. Our sample is necessarily a selected one as only those who experimented with the online process and completed their request for relief received a survey. The survey asked litigants how they had heard about the online assessment program. Responses were varied, and included a postcard, the back of a parking ticket, a clerk referral, a friend referral, a generic web search, and the court's website.

150. This is a conservative number given that only $25 \%$ of these litigants estimated they would have been able to come to court at all. We care more about the percentage of litigants who would have successfully navigated the court's in-person process for receiving an ability-to-pay determination, which, it is worth mentioning, frequently requires multiple visits. 
the court withdrew his original warrant. Moreover, he found the tool easy to use: "[W]alk in court hours, for years, has been very inconvenient. Had it not been for this tool I don't know when I would have been able to handle my tickets!"

Almost $80 \%$ of all respondents felt that their case had been handled fairly. ${ }^{151}$ Given that all of these respondents owed money, and some were facing arrest warrants, the fact that 23 of the 27 people who answered the survey question viewed the process as fair is promising. One respondent emphasized how the traditional approach, which would have required him to miss work, seemed counterintuitive - as a shift worker, he would not have received paid time off and could have been fired for taking time to go to court, which would have decreased his ability to pay his fines. ${ }^{152}$ By contrast, after using the online platform, he felt that his case was handled fairly, that he understood the status of his matter throughout the process, and that he would encourage others to use the platform. We admit, however, that litigants' perceptions of fairness may poorly track accuracy in ability-to-pay assessments. In particular, litigants who receive especially lenient treatment, including those who have intentionally and illegitimately attempted to avoid payment by failing to disclose income or assets, may be inclined to describe the system as fair, ${ }^{153}$ even as they contribute to a different sort of inaccuracy in their ability-to-pay determination. ${ }^{154}$

To better understand the consequences of the online tool, especially with respect to accuracy, we turn now from litigant survey responses to case-level

151. This estimate is calculated by dividing the number of respondents who viewed the process as fair by the total number of respondents $(23 / 29=79.3 \%)$. Dividing instead by the number of those who actually answered the fairness question, 27 , produces an estimate of $85.2 \%$. No respondent indicated that they found the process to be unfair; instead, the remaining four respondents reacted neutrally to the question. We ought to note that all of these respondents and almost all of the users of the assessment tool during this pilot-even those who did not answer the survey question-received some limited form of relief in response to their submission, most often an agreement to a payment plan, but also sometimes the replacement of their owed fines with a community service sanction or a rescheduled court date in the case of a missed court appearance. Courts never or almost never waived a litigants' obligation entirely. Nevertheless, to the extent that respondents are more likely to view the online assessment process as fair if they receive some, albeit limited, relief, less weight should be placed on these estimates. See Youyang Hou et al., Factors in Fairness and Emotion in Online Case Resolution Systems, PrOC. 2017 CHI CONF. ON HUM. FACTORS COMPUTING SYS. 2511, 2516-17 (finding a correlation between perceived fairness and a positive case outcome in a similar setting).

152. The respondent wrote: "Now I have to miss 2 days of work over some tickets I could have paid online. . . now if I loose [sic] my job how would I be able to pay anything?"

153. See supra note 151 .

154. Indeed, one potential direction for future work would be to examine whether litigants are strategic in their response to the availability of an online ability-to-pay assessment tool, and, in particular, whether an online ability-to-pay assessment tool encourages a second sort of inaccuracy by making it easier for some litigants to effectively cheat the system. Among other things, litigants may be less able to prepare for the traditional ad hoc process currently in place, and they may be less willing or able to lie about their means while in open court in the presence of a judge or magistrate. Relatedly, as online platform software becomes standardized, it is possible that litigants will be able to more easily obtain and share information about how to manipulate the system to obtain favorable results. At the same time, platform technology, as it evolves, will likely allow courts of the future to more efficiently and comprehensively tap other sources of financial data and request verifying information to adequately corroborate a litigant's claims. 
litigants and court data, as well as the statements submitted by 163 litigants to court while actually using the Matterhorn tool. The average annual income of these tool users was $\$ 11,604$. These litigants typically had multiple unresolved issues along with their associated fines and fees. The average debt owed was in the $\$ 400$ to $\$ 500$ range, and litigants usually had one or more outstanding arrest warrants for failure to pay or appear. ${ }^{155}$ In these 163 cases, judges completed the online ability-to-pay assessments quickly. Successful litigants were given a payment plan or alternative sanctions, and were thus back in compliance, on average, within four to five days of their seeking relief. For these 163 early users, across all six courts, requesting an ability-to-pay assessment using the online tool almost always ended with all of their outstanding warrants being withdrawn.

Helpfully, the online assessment tool asks litigants whether they have any special circumstances that the court should consider during their ability-to-pay determination. In what follows, we catalog direct quotations from their court submissions. ${ }^{156}$ It is apparent that most if not all of these individuals would have been treated by the system as if they were able to pay had they not had access to the online assessment tool for the simple reason that very few of these litigants would likely have overcome the traditional access barriers to request relief in person. Housing insecurity, bankruptcy, and unemployment were familiar themes, and some extreme measures (e.g., use of shelters, selling plasma) are certainly symptomatic of inability to pay. At a minimum, these litigants would have had to come to court for hours to make their case.

Shirley, 43: "I am a family of 5 with a disabled partner. I am the only source of income. I am currently facing eviction as I am a month behind in rent. I am also facing a shut off for both water and electric. I am desperately seeking assistance but have thus far had no luck. I am doing everything I can to make ends meet and continue to come up short. I would greatly appreciate a low monthly payment to pay this fine off ...."

Mo, 39: "I work 1 day a week ... I understand i did all the above. I was going through a real rough time in my life. The officer only let me go because we were on our way to the shelter. It was really cold out that night. Im trying to right my wrongs. I really cant afford anymore jail time or tickets. Thats why im taking this really serious and im trying to get this matter taken care of."

Michelle, 29: "I have been having difficulty paying this ticket at the full amount because I have had unexpected costs arise every time I get paid, such as having to pay for my son's prescriptions out of pocket and car repairs. I have little money left over after necessary living costs, such as food, gas to get back and forth to work, and child care for my son while I am at work. I do not receive any assistance for my child, although I have applied and been denied for benefits. I have moved back in with my parents after getting out of a violent relationship with my child's father, and I received the ticket driving to get my son from daycare when he had a fever. A payment plan would make it easier for me to include in my budget."

155. Users were on average 33 years old, more likely to be female $(53 \%)$, and often reported having at least one dependent with several reporting caring for a baby or being pregnant. Parents were often single or had a disabled partner or a noncontributing partner, and some indicated they were past victims of abuse and/or had struggled with homelessness.

156. We use pseudonyms for litigants for anonymity. The quotations we present are verbatim with grammatical errors left unchanged. 
Shonda, 24: "Single mom im trying to get on my feet. But only able to donate plasma for money for gas money for my son to get back and forth to school."

Ji, 36: "I am raising three children alone while attending school full time. . . I am trying to get my license back before it gets really cold in Michigan ...."

Maria, 50: "I'm experiencing hardship right now, my vehicle has been repossessed and I am seeking help for foreclosure. I am Currently jobseeking. Whatever little income I've been receiving through Facebook yard sale/yard sale ever tried to distribute to month-to-month bills. I would like to please request a review to possibly lower vibe of the payment until I can get employment to be able to afford more...."

Taneka, 23: "I have been homeless for the past 2 years. I am struggling to complete the CNA program at Central Tech. I am unable to get hired as a CNA because of the traffic warrants I have. The address and phone number I have provided belong to my mother because I currently cannot afford a phone."

Some may question the veracity of these litigant statements, but there are good reasons to think that litigants will be candid when they seek ability-to-pay relief from courts online-or at least no less honest than they would have been in a traditional face-to-face hearing. ${ }^{157}$ It is worth remembering that litigants' online statements are made directly to judges, these statements are retained and remain accessible to the court, and courts can require that documentation verifying a litigant's claims be submitted online. Litigants are also explicitly warned about the legal consequences of misleading the court, ${ }^{158}$ and they are asked to certify the truth of the information they supply. ${ }^{159}$ In any event, if these litigants are being truthful, their statements make plain that many would have struggled to access court in person for an ability-to-pay hearing. Many are not just low-income, but undereducated, disabled, and generally disadvantaged on many levels. ${ }^{160}$ For these litigants in particular, these preliminary data suggest that online platform technology may improve the accuracy of ability-to-pay assessments and reduce the social costs of noncompliance.

157. Although intuition would suggest that lying to a judge online would be easier than lying to a judge's face, the question of whether people are more likely to lie online is complicated and may depend critically on context. See Melissa Stanger, People Are Actually More Honest Online Than In Person, BUSINESS INSIDER (Dec. 28, 2012), https:/www.businessinsider.com/people-are-more-honest-online2012-12 [https://perma.cc/EB7J-72BX]. But see Raina Ducklow \& Bud Mortenson, What Lies Behind the Online Words?, UBC REPORTS (Apr. 2, 2009), https://news.ubc.ca/2009/04/02/archive-ubcreports-200909apr02-behind/ [https://perma.cc/4MEQ-XT6U].

158. As the litigants in our sample began the assessment, they were reminded: "Keep in mind - it's a felony to provide false information to the court. If you say you're unemployed or have zero cash and you actually have a good-paying job and few expenses, that's going to be a problem. That said, the court isn't going to throw you in jail if, for example, your checking account has $\$ 200$ in it today and happens to be $\$ 400$ when they review. Trust the court, just as the court trusts you to provide honest, truthful information in order to work out a fair game plan, so we can all move on!"

159. Specifically, litigant users must agree to the following statement: "I certify under penalty of perjury that this financial statement is a complete and accurate statement of my income, assets, and expenses, and that I have no additional income."

160. William Julius Wilson, The Truly Disadvantaged: The Inner City, The UNDERCLASS, AND PUBLIC POLICY (2d ed. 2012). 


\section{VI \\ CONCLUSION}

For fines to work well as alternative sanctions in our justice system, courts need an accurate means of determining an individual's ability to pay. For the poor, even modest fines for minor offenses can make compliance with the law cost prohibitive, and when an individual is unable to pay a fine, enforcement efforts (e.g., civil contempt sanctions) are not just ineffective but actually counterproductive, as they are expensive to impose and make it more difficult for individuals to earn what they owe. The U.S. Constitution prohibits a court from jailing someone who is unable to pay a certain fine amount, ${ }^{161}$ but current abilityto-pay proceedings are unstructured and anemic, if they occur at all. Not surprisingly, many thousands of people a year who are rather demonstrably unable to pay their outstanding court debt are jailed notwithstanding their lack of financial means. ${ }^{162}$ This systematic inaccuracy is costly for these individuals, their families, the courts, and society.

In the last few years, a number of states have sought to improve matters. Not surprisingly, most have focused on making the substance and process of abilityto-pay determinations more robust. ${ }^{163}$ At least a few courts, however, have turned instead to online platform technology in the hopes of establishing consistent, efficient, and accurate ability-to-pay assessment hearings that take place online. Online assessment tools in particular seek to ease access issues - making it easier for litigants to make their case effectively and without missing work - while also collecting, distilling, and delivering all relevant information to judges in a more uniform, comprehensive, and efficient manner. ${ }^{164}$

Although we rely on limited information in this study, our preliminary evidence suggests that online assessment tools very likely improve the accuracy of ability-to-pay determinations. We acknowledge that we present just one piece of the puzzle in this short article. We do not present a comprehensive picture of the tradeoffs of adopting online platform technology to resolve disputes, including the possibility that face-to-face hearings may be essential in some circumstances but prejudicial in others and that online interactions may be more or less open to litigant manipulation or judicial shirking than traditional courthouse proceedings. Even the empirical picture of improved access and efficiency that we $d o$ present is a tentative one. There is much work that remains to be done. ${ }^{165}$ Nevertheless, the interview, survey, and case-level court data we analyze give us useful qualitative evidence on important dimensions of the relative attractiveness of online ability-to-pay determinations versus in-court proceedings. At a minimum, we learn that online ability-to-pay assessment

161. Bearden v. Georgia, 461 U.S. 660, 672-73 (1983).

162. Supra note 51 and accompanying text.

163. See supra Part IV.

164. See supra notes $96-104$ and accompanying text.

165. Some of this work has been done elsewhere. See generally Bulinski \& Prescott, supra note 57; Prescott, supra note 13. 
proceedings can improve communication between judges and litigants with respect to certain topics, that many litigants are unable to access traditional proceedings and can therefore end up with default outcomes that are often substantively incorrect, and that the online approach to transmitting case data is often more efficient and delivers more comprehensive information from the judge's perspective, which presumably facilitates better decisions. Alone, these indicia suggest that online platform tools in general may have an important role to play in making the use of fines as sanctions fairer and more effective. 